\title{
Plasticity of human adipose-derived stem cells - relevance to tissue repair
}

\author{
LEONARDO GUASTI', SOPHIE E. NEW², IRENE HADJIDEMETRIOU1,2, MIRIAM PALMIERO² \\ and PATRIZIA FERRETTI2

\begin{abstract}
${ }^{1}$ Centre for Endocrinology, William Harvey Research Institute, Barts and the London, Queen Mary University of London and 'Stem Cell and Regenerative Medicine Section, Developmental Biology and Cancer Programme, UCL Great Ormond Street Institute of Child Health, University College London, London, UK.
\end{abstract}

\begin{abstract}
In contrast to cold blooded vertebrates, the ability to regenerate morphologically and functionally complex structures is limited in adult mammals. Recruitment of progenitor cells is a key step in the regenerative process. The possibility of repairing missing or diseased tissues in humans has been potentiated by the increasing understanding of somatic stem cells, their plasticity and the possibility of modulating it, that could be harnessed either to stimulate endogenous repair or to engineer the required tissue. Here, we focus on human mesenchymal stem cells (MSCs), important players in tissue homeostasis in healthy organisms, with a particular emphasis on those derived from the adipose tissue (ADSCs). While a mark of MSC identity is the ability to differentiate into osteoblasts, chondrocytes and adipocytes, there is evidence that their potential goes beyond these three mesenchymal lineages. We discuss some differentiation and modulatory properties of MSCs and provide an overview of our recent work on ADSCs from paediatric patients (pADSCs) that has shown their ability to give raise to non-mesenchymal cells, consistent with a significant plasticity. Finally, we present novel data indicating that both mesenchymal lineages (adipogenic, chondrogenic and osteogenic) and neural and epithelial lineages can originate from clonal lines that like the parental line express markers of pluripotency as well as the stromal cell marker, GREM1. Together these data support the existence of pADSC multipotent stem cells.
\end{abstract}

KEY WORDS: adipose tissue-derived stem cell (ADSC), human, mesenchymal stem cell (MSC), plasticity, regeneration

\section{Introduction}

The possibility of regenerating entire organs has fascinated humankind for centuries given the limited regenerative ability in humans in contrast to extraordinary regenerative capabilities observed in certain species where entire body structures can be fully replaced. For example, cold blooded vertebrates, such as fish and amphibians, can regenerate limbs, jaws, tails, heart, and even their nervous system, spontaneously (Berg et al., 2010, Ferretti and Géraudie, 1998, Goss, 1969, Slack, 2017, Spallanzani, 1768, Stocum, 2006, Tzahor and Poss, 2017). Regeneration occurs via formation of a mound of undifferentiated progenitor cells, the blastema, in response to injury. The mechanisms underlying mobilization of these cells, their origin and differentiation potential has been a matter of much debate for several decades, and obviously depends on the tissue/organ to be replaced and the species studied (Godwin, 2014, Zielins et al., 2016).

Recruitment of progenitor cells is a key step in the regenerative process and the ability to stimulate it in mammals represents a potential strategy for inducing regeneration in humans, as exemplified by studies on mammalian digit tip regeneration (Agrawal et al., 2010, Simkin et al., 2015). Furthermore, a crucial role of inflammatory responses in stimulating regeneration in several species has emerged over the last few years, with a key role for inflammatory cells demonstrated following digit tip amputation and regeneration of the skin in the African spiny mouse (Godwin, 2014, Simkin et al., 2017). Another approach to circumvent the limited regenerative

Abbreviations used in this paper: ADSC, adipose-derived stem cell; MSC, mesenchymal stem cell; WAT: white adipose tissue.

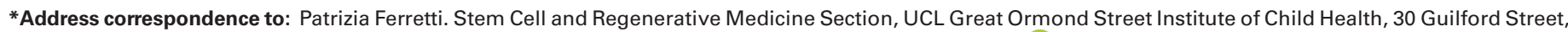
London WC1N 1EH, UK. Tel: (+44) 020-7905 2372. Fax: (+44) 0207905 2953. E-mail: p.ferretti@ ucl.ac.uk - ID https://orcid.org/0000-0002-3590-6772
} 
ability in mammals is the use of autologous or allogeneic cells to engineer tissue for reconstructing structures damaged by injury, disease or birth defects. Whichever approach one might wish to take to improve repair of human tissues, a thorough understanding of developmental mechanisms leading to formation of the structure of interest in vivo and of the potential for repair of human progenitor cells, both pre- and post-natally, is crucial. Investigation of mechanisms governing development, cellular plasticity, and normal and abnormal function of human tissues is hampered by the very limited possibility of experimental manipulations of human tissues in vivo. Hence, most of our understanding of cellular and molecular mechanisms governing human development and repair is either extrapolated from animal studies, that do not always reflect human cell behavior or disease presentation, or in vitro systems.

Among human tissues with very limited regenerative capability are the bone and cartilages of the craniofacial skeleton. In fact, while skeletal fracture healing is a fairly efficient process, in humans critical size skeletal defects are not spontaneously repaired. This is in contrast to salamander and fish ability to fully regenerate their jaws, in addition to their appendicular skeleton, upon recruitment of mesenchymal progenitor cells to form the blastema (Ghosh et al., 1996, Paul et al., 2016). Here mesenchymal cells are key players in the regenerative process, but humans do not seem able to effectively activate them to repair large skeletal defects.

Consequently, widely investigated cell types for developing novel treatment modalities for craniofacial defects in humans are Mesenchymal Stem Cells (MSCs). Since the discovery of MSCs in the human bone marrow in 1968 (Friedenstein et al., 1968) there has been an ever-increasing interest in these cells. MSCs are known to be important for tissue homeostasis, but cannot regenerate missing bone or cartilage in humans. Therefore, much focus has been on their potential use in cell-based therapies for repairing damaged tissue, which has resulted in hundreds of current and planned clinical trials (Squillaro et al., 2016). The interest in using MSCs to repair these tissues has obviously generated a huge number of papers on their characterization, and raised a number of questions about the specific identity and properties of MSCs from different tissues and their plasticity.

In depth discussion of the huge wealth of studies and of differ- ences between human MSCs from different tissues is beyond the purpose of this article. Here we will briefly discuss some properties and origin of MSCs with a particular focus on those derived from adipose tissue (ADSCs), and provide an overview of our recent published work on ADSCs from paediatric patients (pADSCs) in the context of current knowledge. We will also discuss novel data supporting pADSC plasticity and their ability to give raise to nonmesenchymal cells.

\section{Mesenchymal stem cell (MSC) properties and origin}

MSCs are multipotent stem cells with high capacity for selfrenewal and expansion; they are endowed with differentiation potential to various lines, including, but as we will discuss later not limited to, osteoblasts, chondrocytes, and adipocytes. They can be found virtually in all tissues and are believed to reside mainly within the perivascular niche.

MSCs are routinely isolated as the so-called "stromal fraction" from the vast majority of human tissues (Fig. 1), both adult and paediatric, as well as from extra-embryonic tissues (umbilical cord, placenta and amniotic fluid) (Stubbendorff et al., 2013).

Post-natally, common sources of MSCs are the bone marrow, adipose tissue and dental pulp. MSCs have been characterized extensively after culture in vitro; however, this procedure selects cells on their ability to adhere to plastic surfaces or other substrates, as well as to expand after adhesion; therefore the resulting cell population may display some different features from the native stromal fraction it was derived from. A set of cell surface markers is used to characterize MSCs, usually by flow cytometry; although some of these markers, as exemplified in Table 1, are common to MSCs derived from diverse sources, differences in the expression of others have been described. These differences reflect features of the tissue of origin and culture conditions (Hass et al., 2011, New et al., 2015). Furthermore expression of "MSC" surface markers seems to be shared also by other somatic stem cells, calling for caution on classifying cells as MSC only on the basis of these markers (New et al., 2015).

Somatic stem cells had not been classically considered to be highly plastic, but the plasticity of human MSCs is now well

\section{IN VIVO IN VITRO}

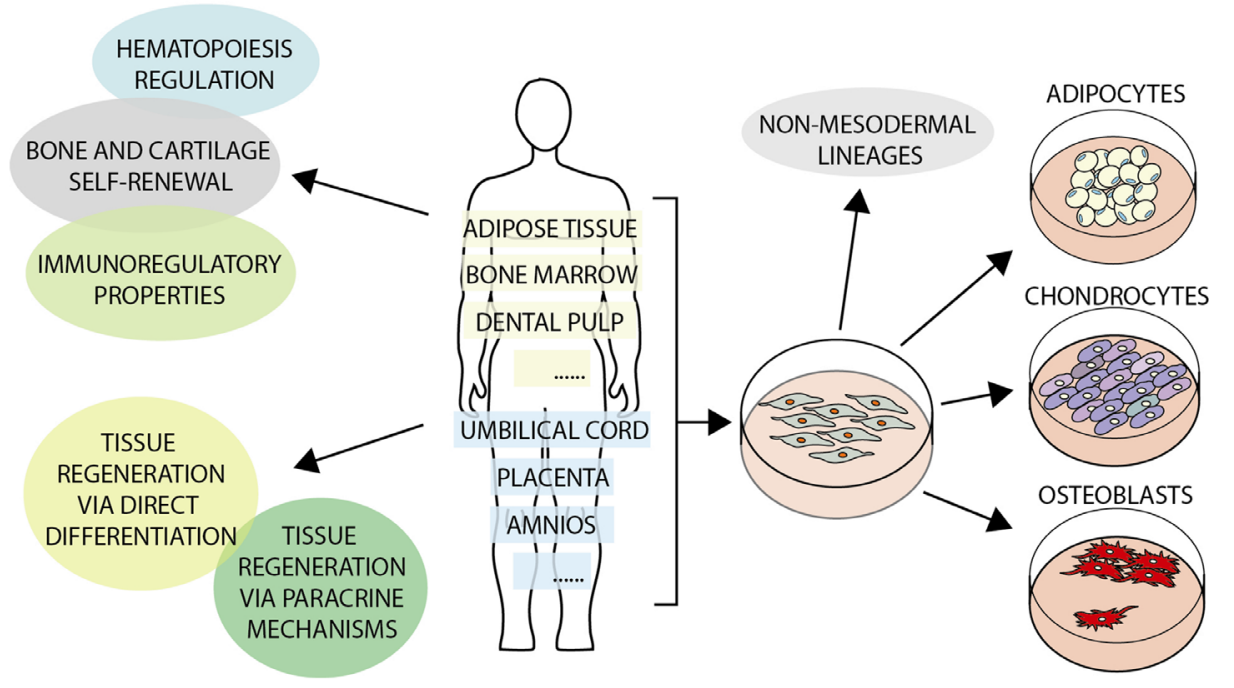

Fig. 1. In vivo and in vitro characteristics of mesenchymal stem cells (MSCs). MSCs can be isolated from tissues of both adults and children, as well as from extra-embryonic tissues. They have been extensively studied for their in vitro ability to differentiate towards mesodermal lineages (adipocytes, chondrocytes and osteocytes), and specific protocols to generate cells of non-mesodermal lineages have been developed. In vivo, MSCs' most studied properties regard hematopoiesis regulation, the self-renewal of bone and cartilage and their potent immunoregulatory properties. The versatility typical of MSCs is being investigated for tissue regeneration purposes, either via their direct differentiation towards tissues to be engineered or by taking advantage of the actions of their secretome. 
TABLE 1

\section{COMPARATIVE ANALYSIS OF SURFACE MARKERS OF HUMAN UC-MSC, p-ADSC AND NSCs, BY FLOW CYTOMETRY}

\begin{tabular}{|c|c|c|c|c|}
\hline & & UC-MSC & p-ADSC & NSC \\
\hline \multirow{7}{*}{ 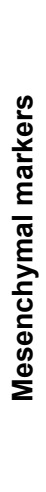 } & CD13 & $97.48 \pm 1.4$ & $97.43 \pm 2.16$ & $82.07 \pm 9.53^{*}$ \\
\hline & CD29 & $99.28 \pm 0.51$ & $98.70 \pm 1.15$ & $99.90 \pm 0.10$ \\
\hline & CD44 & $98.98 \pm 0.80$ & $99.87 \pm 0.03$ & $99.83 \pm 0.06$ \\
\hline & CD73 & $98.28 \pm 1.01$ & $99.17 \pm 0.68$ & $99.47 \pm 0.33$ \\
\hline & CD90 & $98.95 \pm 0.85$ & $99.07 \pm 0.23$ & $67.13 \pm 24.65$ \\
\hline & CD105 & 99.00 & $92.43 \pm 6.18$ & 57.20 \\
\hline & CD166 & $97.00 \pm 1.55$ & $92.30 \pm 6.45$ & $99.50 \pm 0.15$ \\
\hline
\end{tabular}

UC-MSC umbilical cord mesenchymal stem cell; pADSC, paediatric adipose-tissue derived stem cell; NSC, neural stem cell (modified from New et al., 2015).

documented, though much variation between studies is noted; this is likely due to differences in experimental conditions, individual donors genetic background, or a combination of the two (Hass et al., 2011, Ullah et al., 2015). While a general definition of MSCs is based on their 3 mesenchymal lineage differentiation potential (cartilage, bone and adipose), it has been proposed that they harbor also myogenic capability (Rodriguez et al., 2006, Stern-Straeter et al., 2014, Szaraz et al., 2017). In addition, cells of non-mesodermal lineages, such as hepatocytes, endothelial, epithelial, pancreatic and neural cells have also been derived from MSCs using specific cocktails of cytokines and chemical compounds (Bekhite et al., 2014, New et al., 2017, Ullah et al., 2015). Furthermore, MSCs have been reprogramed to Inducible Pluripotent Stem Cells (IPSCs) using pluripotency transcription factors, or reprogrammed to directly generate specific tissue types through forced expression of lineage-specific transcription factors (Hynes et al., 2016). Overall, MSCs from different sources seems to share the property of being more easily reprogrammed than mature somatic cells, such as fibroblast and blood cells; this appears to correlate with expression, though at low levels, of pluripotency transcription factors (Galende et al., 2010, Guasti et al., 2012, Streckfuss-Bomeke et al., 2013, Sun et al., 2009).

Despite the comprehensive characterization of MSCs properties in vitro, much less is known regarding their exact location in the tissues of origin and their precise role in the regulation of tissue homeostasis. A better understanding of these two aspects would certainly facilitate the exploitation of their translational potential. Several recent independent studies have shown that cells with MSCs properties can be localized in and isolated from perivascular locations in the tissues of origin (Murray and Peault, 2015); however, MSCs not associated with the vasculature have been identified in certain structures, such as cranial sutures (Zhao et al., 2015). The MSCs associated with the vasculature, the so called Perivascular Stem Cells (PSCs), are seemingly pericytes and adventitial cells, and appear to contribute to local tissue repair upon activation in response to injury (Crisan et al., 2008, da Silva Meirelles et al., 2015). PSCs, like all MSCs studied, display an important property, which is immunomodulation; in fact they have been shown to secrete discreet set of cytokines as well as activate T suppressor lymphocytes, resulting in a complex immunosurveillance during the repair process (Blanco et al., 2016, Gebler et al., 2012, Melief et al., 2013). This potent immunomodulatory role is indeed being harnessed in clinical trials aimed, for example, at ameliorating graft versus host disease, improving allogenic stem cell transplants or function in diseased liver and kidney (Gao et al., 2016, Squillaro et al., 2016). However, evidence for a significant role of grafted cells in tissue regeneration has yet to be provided.

As it has become more and more apparent that beneficial effects of MSCs are mediated via paracrine mechanisms, there has been much interest in defining the secretome of these cells as well as identifying approaches to activating/mobilizing them in the hope of developing cell-free therapies and harness any endogenous regenerative potential (Embree et al., 2016, Mele et al., 2016, Miller and Kaplan, 2012). The initial focus has been on growth factors and cytokines, but a cocktail of MSC-secreted growth factors and cytokine that mimic closely the effect of injected MSCs has yet to be defined (Toh et al., 2017). More recently, the therapeutic potential of MSC-derived exosomes has come to the forefront. Exosomes are 30-150 nm secreted vesicles that carry proteins, nucleic acids (e.g. microRNAs) and lipids and are now believed to play key functions in cell-cell communications both at short and long range (Thomou et al., 2017). Recent studies reporting beneficial effect of adipose stem cell exosomes in a range of animal disease models, including skin wound healing, revascularization, amyotropic lateral sclerosis and myocardial ischemia, are galvanizing interest in exploiting their properties to develop novel therapeutic approaches (Cui et al., 2017, Hu et al., 2016, Kang et al., 2016, Lee et al., 2016). Furthermore, the ability of MSC to exchange materials at a shorter range via tunnelling nanotubes has also been suggested (Vignais et al., 2017).

Finally, it has been recently shown that stem cells expressing typical MSC surface markers are present in fibrocartilage and that modulation of Wnt signaling plays an important role in the maintenance of this cell pool. Significantly, in vivo treatment with a Wnt inhibitor, sclerostin, induced cartilage formation and aided repair in an injured temporomandibular joint (Embree et al., 2016). While the possibility of stimulating endogenous MSCs for tissue repair in humans is still in its infancy, this study provides proof of principle that by better understanding basic mechanism modulating tissue homeostasis it will be possible to develop minimally invasive effective treatments.

\section{Adipose tissue and adipose tissue-derived stem cells}

The human ADSCs most commonly studied are derived from white adipose tissue (WAT), whose function is to store fuel while acting as a proper endocrine organ by secreting leptin and adiponectin, two key energy homeostasis regulators. Heterogeneity in the biology of adipose cells within the WAT has been reported to be linked to sex, ethnicity, age and location of body depots (e.g. visceral versus subcutaneous adipose tissue); these differences can be both structural and molecular (e.g. cytokine production) (Badimon and Cubedo, 2017, Tchkonia et al., 2013). It is not currently clear whether differences in mature WAT are mirrored by differences in 
the biological properties of their precursors. The more widely used source of WAT for stem cell research is the subcutaneous abdominal fat.

The developmental origin of WAT is still largely unknown, however the advent of transgenic models, especially those with a Cre/Loxp-based tracing, has enormously helped to shade light on the embryological origin of WAT as well as the characterization of local progenitor cells within the adult organ, at least in animal models. The initial finding that peroxisomeproliferation-activated receptor $\gamma$ (PPAR $\gamma$ ) expression is an early marker of adipocyte commitment, and that precursors are located in the mural compartment of the adipose tissue as PDGF $\beta$ (platelet-derived growth factor receptor $\beta$ ) -positive cells, paved the way for other studies aimed at localizing and determining the phenotype of adipose tissue progenitor cells (Tran et al., 2012). An intriguing property underlying plasticity of WAT precursor is that they may be bi-potential and able to generate both adipose and endothelial cells, as the studies tracing the expression of zinc finger protein 423 (Gupta et al., 2010, Gupta et al., 2012) and VE-cadherin (Tran et al., 2012) have suggested; however other studies have contradicted these data (Berry and Rodeheffer, 2013). Embryologically, initial studies suggested that WAT originate from Myf5 (myogenic Factor 5)-negative precursors, unlike brown adipose tissue (BAT) and skeletal muscle which might share common Myf5-positive precursors (Seale et al., 2008, Timmons et al., 2007). However, it is now clear that some WAT cells can arise from Myf5-positive precursors. Lineage tracing using novel mouse models is shedding light on the high degree of complexity and heterogeneity of the developmental origin of WAT where different precursors may be recruited depending on the location of the fat depot (reviewed in Sanchez-Gurmaches and Guertin, 2014). For example, in mice the anterior subcutaneous and retroperitoneal WAT (as well as BAT) likely derive from a mixed population of Myf5-positive and Myf5-negative precursors, though enriched in Myf5-positive cells, while inguinal and perigonadal WAT arise mostly from a Myf5-negative line.

Intriguingly, analysis of abdominal WAT in humans who had received bone marrow stem cells (BM-MSCs) or mobilized peripheral blood stem cells transplants indicated the presence of donor-derived adipocytes, that are more likely derived from BM-MSCs than from haematopoietic progenitors (Ryden et al., 2015). It is not clear, however, whether BM-MSCs contribute to the progenitor pool in the stromal fraction. Furthermore, given the ability of adipocytes to dedifferentiate in vitro (Matsumoto et al., 2008), it is also conceivable that some of the cells present in fat-derived cultures might be of BM origin. The plasticity observed in vitro might not be only a feature of cultured cells. It has been recently suggested that ADSCs can transdifferentiate in vivo when injected in the mammary gland and contribute to the growing ducts by acquiring an epithelial phenotype (De Matteis et al., 2009).

Although WAT origin is still not well understood, discreet set of cell surface markers that selectively recognize WAT progenitors have been described, even though no single marker is widely accepted for their localization and/or isolation in vivo. A study identified a population (CD45-, CD31', Lin', CD29+, Sca1 ${ }^{+}, \mathrm{CD}^{-} 4^{+}, \mathrm{CD}^{-} 4^{+}$) of progenitors that is able to regenerate WAT upon transplantation into lipodystrophic mice (Rodeheffer et al., 2008). However, depotand even strain-specific differences in the presence and levels of expression of those cell surface markers have subsequently been reported (Joe et al., 2009, Macotela et al., 2012).

ADSCs have been extensively studied for their differentiation potential towards several lineages, both mesodermal and extra mesodermal. For example, we have described the high plasticity of ADSCs established from paediatric donors (pADSCs), and shown that selective skeletogenic differentiation is highly dependent on the induction medium (Guasti et al., 2012). While there has been some indication that human ADSCs harbour also potential for myogenic differentiation (Desiderio et al., 2013, Stern-Straeter et al., 2014), we have been unable to unveil it in pADSCs using a variety of protocols including standard muscle differentiation protocols and small molecules; whether this reflects differences between adult and paediatric, or normal and patient-derived tissues, or differences in the experimental settings, remains to be elucidated. Nonetheless, pADSCs display significant plasticity, as they can easily undergo not only chondrogenic and osteogenic differentiation, but also differentiate towards neuroectodermal lineages. When exposed to a neural induction mediun containing valproic acid, pADCSs differentiate towards neuronal-like cells (Guasti et al., 2012, New et al., 2015). In addition, we have shown that they acquire an epithelial-like morphology when treated with retinoic acid (RA), a small lipophilic molecule that directs several differentiation processes during development and induces regeneration in several systems (Maden and Hind, 2003). The occurrence of epithelial differentiation has been supported both by changes in gene and protein expression and by functional assays. Formation of tight junctions, detected by selective translocation of Zona Occludens-1 (ZO1) protein to establish cell-to-cell contacts, and induction of 
cytokeratin 18 (CK18), that with K8 is expressed by simple epithelia at early developmental stages, was observed (New et al., 2017). In addition, that study showed the barrier forming potential of the epithelially-induced pADSCs. The epithelial differentiation capability of pADSC we have observed is consistent with both in vitro and in vivo studies showing the ability of adult ADSCs to generate epithelia of endodermal origin (like most airway epithelia), such as the urothelium (Baer, 2011, Li et al., 2014).

Significantly, the possibility of differentiating and co-culturing pADSC-derived cartilage and epithelium can be valuable both for modeling human tissue interactions to investigate cellular and molecular mechanisms of disease as well as for "organ" engineering. ADSCs are amongst the most promising MSCs for clinical application in autologous reconstructive surgery as they can be easily harvested using minimally invasive techniques with extremely low morbidity, even from paediatric patients, as well as displaying immunomodulatory properties like MSC from other sources. Hence pADCSs could potentially be harnessed in more complex translational settings, where both cartilaginous and epithelial tissues are required, such as for reconstructing deformities of the upper airways, including those of the nose and throat. While discussion of pADCSs potential for tissue reconstruction in patients with craniofacial deformities is not within the scope of this article, it should be noted that selective differentiation of pADSCs to chondrocytes can also be achieved within novel bioscaffolds, which are cyto-compatible for tissue engineering applications, such as POSS-PCU (polyhedral oligomeric silsesquioxane poly(carbonate-urea) urethane) and POSS-PCL (polyhedral oligosilsesquioxane-poly( $\varepsilon$-caprolactone) (Griffin et al., 2017, Guasti et al., 2014, New et al., 2017).

\section{Are pediatric ADSCs truly plastic?}

It has long been questioned whether somatic stem cells are indeed multipotent stem cells, or a heterogenous population of cells composed of subsets of unipotent progenitor cells. Some studies have supported the hypothesis that adult human ADSCs are multipotent stem cells, but one early study has suggested that not all clones possess the ability to undergo trilineage differentiation (Guilak et al., 2006, Stillwell et al., 2012). Hence we carried out clonal analysis of pADSCs to test whether their apparent plastic- ity could be due to a fraction of the cell population endowed with multipotency or to different cells which can differentiate only into one or two lineages.

\section{Results and Discussion}

We isolated clones from ADSCs of a paediatric donor (male, age 16) by limiting dilution, with successful derivation of clones from $50 \%$ of visible single cells. The parent line displayed threelineage differentiation potential (adipogenic, chondrogenic and osteogenic) as all the pADSC lines generated in our laboratory (>40) from paediatric patients (age range 7-17 years).

Previous studies had demonstrated expression of pluripotent markers in pADSCs and suggested that this may underlie their plasticity (Guasti et al., 2012, Park and Patel, 2010). In order to establish whether this pattern of expression was maintained in clonal lines, we assessed expression of KLF4 (KRUPPEL-LIKE FACTOR 4), OCT4 (OCTAMER-BINDING PROTEIN 4, also known as POU domain, class 5 , transcription factor $1, P O U 5 F 1$ ) and NANOG (transcription factor named after Tìr nan Òg, the mythical Celtic land of youth) in the parental line, 3 clones and human embryonic stem cells (hESCs). As shown in Fig. 2, gene expression levels of OCT4 and NANOG were lower both in the parental pADSC line and in the clones, when compared to the levels found in hESCs, whereas KLF4 expression was considerably higher in pADSCs. No significant differences were observed in the expression levels of these factors between clones. A previous paper correlated the high expression of KLF4 with a more pluripotent phenotype, closer to that of an ESC. As well as an indicator of "stemness", KLF4 regulates a number of different cellular processes including proliferation, differentiation and apoptosis. Interestingly, KLF4 was found to inhibit endodermal differentiation in murine ESCs (Aksoy et al., 2014). The high levels of KLF4 in pADSCs may play an important role in maintaining their undifferentiated status.

In contrast to ESCs, parental pADSCs and clonal lines expressed high levels of GREM1 (GREMLIN 1). GREM1 is a BMP (bone morphogenetic protein) antagonist that has been recently reported to identify clonogenic stem cell populations within the bone marrow and the intestine connective tissue in mice (Worthley et al., 2015). Expression of GREM1 in pADSC is consistent with self-renewal of
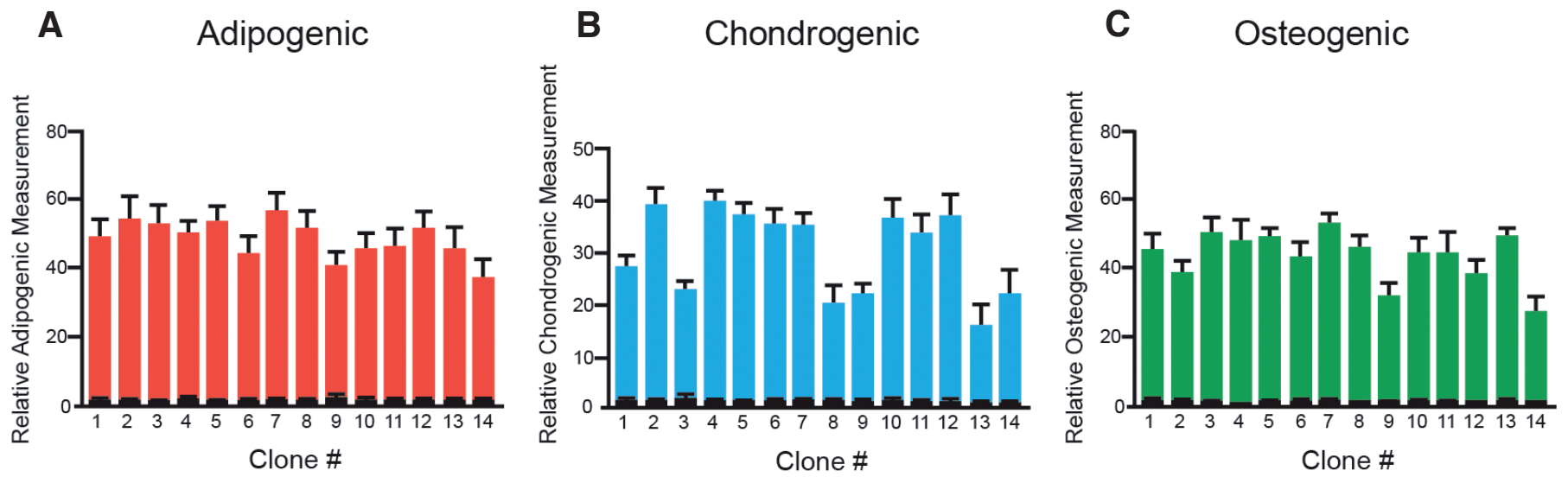

Fig. 3. Effect of induction of adipogenic, chondrogenic and osteogenic differentiation in three paediatric adipose-tissue derived stem cell (pADSC) cloned lines. Fourteen clones obtained from a single donor were differentiated towards (A) adipogenic, (B) chondrogenic and (C) osteogenic lineages for 21 days and then stained with Oil Red O (adipogenic), Alcian Blue (chondrogenic) and Alizarin Red (osteogenic) and quantified. As controls, cells were kept in non-inducing media for the same time. Mean \pm SEM, triplicate biological samples per clone, differentiated samples in colour, controls in black. 
these cells, as even lines maintained in culture over 20 passages are still able to undergo multilineage differentiation, though their duplication time becomes a bit slower at around passage 10 .

Clones were then tested for their mesenchymal differentiation capability by treating them with adipogenic, chondrogenic and osteogenic induction media; as shown in Fig. 3 all clones were able to differentiate towards the three lineages, albeit with different efficiencies (Fig. 3 A-C). Together, though not all of the single cells were able to expand efficiently, those that did clearly possessed multilineage mesenchymal potential. This supports the existence, within the pADSC cultures, of cells with intrinsic plasticity towards mesodermal lineages.

Having previously shown that pADSC can undergo non-mesodermal differentiation, we next investigated clonal line potential for epithelial and neuronal differentiation by comparing three clones and the parental line they were derived from. Following epithelial induction of pADSC clones $(n=6)$, a general trend in up-regulation of the epithelial marker cytokeratin-18 (CK18) was observed in all clones and the parental line at the transcriptional level (Fig. 4A). The tight junction marker, zonula occudens-1 (ZO-1), was unchanged upon epithelial induction at a transcriptional level (not shown), but a clear translocation of ZO-1 from the cytoplasm to the plasma membrane after induction was noted in all the clones by immunocitochemistry (Fig. 4B).

Following induction of the clones with neurogenic media, a general trend in up-regulation of neural markers at the transcriptional level was noted (Fig. 4C). The neuronal marker transcript, neuron-specific enolase (NSE), and the Schwann cell marker, PO, were increased in all clones, albeit to varying degrees and with some differences in their time-course. The neurogenic potential of the pADSC clones was also investigated at the protein level. Protein expression of the neuronal markers, NF-200 and MAP2 (Fig. 4D), was assessed by immunofluorescence in pADSC clones. An increase in neural marker staining was obseved in all clones tested $(n=5)$. Whereas induction of neural markers was clearly observed here and consistent with previous studies, we have no evidence that neurally induced cells, either from parental or clonal lines, can develop into mature neurons or glia. Both our previous work with a different type of MSCs, the amniotic fluid-derived stem cells, and studies of adult ADSC from other groups cast doubts on the possibility of inducing true neurogenic differentiation in MSCs without genetic manipulations (Arribas et al., 2014, Prasongchean et al., 2012).

\section{Concluding remarks}

Notwithstanding intense research in the field, much has yet to be understood about the in vivo behavior and tissue-specific properties of human MSCs. Endogenous MSCs are not able to spontaneously mount a significant regenerative response in humans and reconstruct skeletal critical size defects. The possibility of recruiting them following injury in a similar fashion to that observed in control (undiff).
B

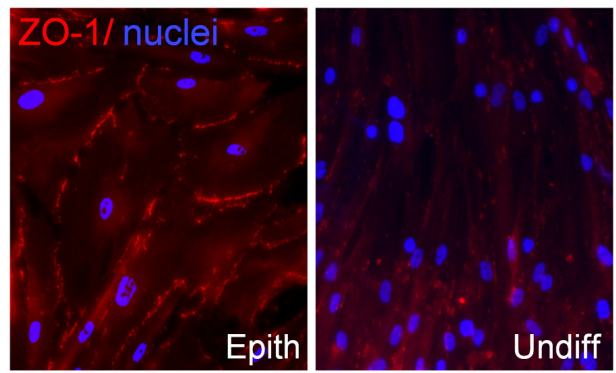

D
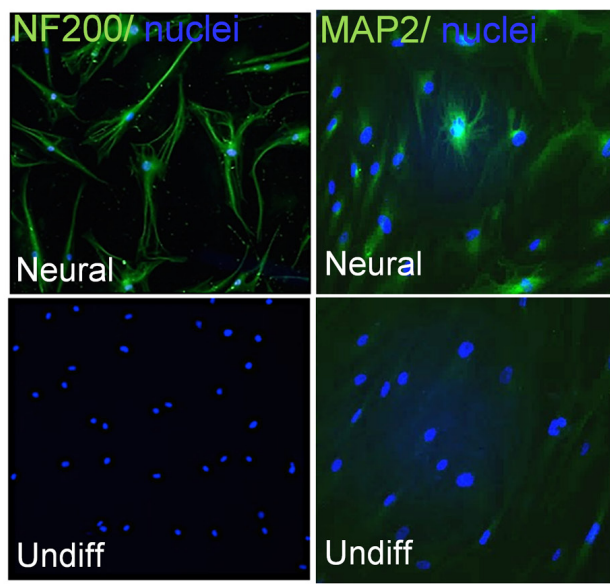

Fig. 4. Effect of induction of epithelial and neural differentiation in paediatric adiposetissue derived stem cell ( $p A D S C$ ) cloned lines as compared to the parental line. (A) $R T-q P C R$ analysis of CK18 expression in 3 pADSC clones epithelially differentiated for 4 . (B) Representative image of expression and cellular localization of ZO-1 in a clone rol (Undiff). (C) RT-qPCR analysis of neuronal (NSE) and glial (P0) marker expression MAP2 expression in a neuronally induced clone of pADSCs and in the undifferentiatiate

regenerating organs of fish and amphibians remains to date fairly remote. A more extensive knowledge of mechanisms governing regeneration in these systems as well as a better understanding of the biology of human endogenous MSCs in vivo will be needed to achieve this goal.

Human MSCs display significant plasticity in vitro, that, at least in the case of ADSCs from young individuals, appears to reflect the existence of a multipotent stem cell population; to some extent this plasticity may also be expressed in vivo, as grafted MSCs can home and differentiate at sites different from those they originated from. For what MSC potential in replacing missing structures is concerned, in the medium term their therapeutic value seems to lay mainly in their multilineage differentiation potential that can be harnessed for bioengineering different tissues.

Importantly, there is evidence from in vitro studies and grafting experiments in animals, as well as from some clinical trials, that MSCs are endowed with significant modulatory properties that can reduce damage and possibly contribute to functional repair in some diseased tissues.

In conclusion, these are indeed exciting times for human MSCs in the context of tissue damage and repair. 


\section{Materials and Methods}

All chemicals were from Sigma-Aldrich, unless otherwise stated.

\section{Human paediatric adipose tissue-derived stem cells}

Abdominal adipose tissue was aspirated from consenting paediatric patients under ethical approval from the Camden and Islington Community Local Research Ethics Committee (London, UK). pADSCs used in this study were isolated from a 16 year old male as previously described (Guasti et al., 2012, New et al., 2017) and cultured in high glucose DMEM (Dulbecco's modified Eagle's medium) with GlutaMAX ${ }^{\mathrm{TM}}$, supplemented with $10 \%$ ESFBS (ES-qualified foetal bovine serum) and 1\% penicillin/streptomycin. Cells were grown in humidified incubators at $37^{\circ} \mathrm{C}$ with $5 \% \mathrm{CO}_{2}$.

\section{Clonal expansion}

pADCSs were detached from the flask with trypsin-EDTA, counted and plated at a density of 0.8 cells/well in 96 -well plates. Microscopic examination confirmed the presence or absence of single cells in wells. Medium was replaced twice a week, and when confluent, cells were amplified for experiments.

\section{Differentiation}

Differentiation was induced in clonal populations of pADSCs as previously described, by replacing the media with DMEM containing GlutaMAX $^{\mathrm{TM}}, 1 \%$ penicillin/streptomycin, 10\% ES-FBS supplemented with a specific cocktail for either the mesenchymal (adipogenic, osteogenic or chondrogenic), epithelial or neural lineages (Guasti et al., 2012, New et al., 2015). The composition of the induction media used was as follow, 1) Adipogenic: DMEM 10\% embryonic stem cells-qualified (ES)-FBS, $10 \mathrm{ng} /$ $\mathrm{ml}$ insulin, $500 \mu \mathrm{M}$ 3-isobutyl-1-methylxanthine, $1 \mu \mathrm{M}$ dexamethasone, and $1 \mu \mathrm{M}$ rosiglitazone (Molekula); 2) Chondrogenic: DMEM 10\% ES-FBS, 0.1 $\mu \mathrm{M}$ dexamethasone, $10 \mathrm{ng} / \mathrm{ml}$ transforming growth factor (Tgf) $\beta 1$ (R\&D Systems), insulin-transferrin-selenium (ITS) (Life Technologies), and $50 \mu \mathrm{g} /$ $\mathrm{ml}$ ascorbate; 3) Osteogenic: DMEM 10\% ES-FBS, $0.1 \mu$ M dexamethasone, $100 \mu \mathrm{g} / \mathrm{ml}$ ascorbate, and $10 \mathrm{mM} \beta$-glycerophosphate, 4) Neural: DMEM with Glutamax supplemented with $1 \%$ penicillin/streptomycin, $10 \%$ ES-FBS, $10 \mu \mathrm{M}$ forskolin, $5 \mathrm{mM} \mathrm{KCl}, 2 \mathrm{mM}$ valproic acid, $1 \mu \mathrm{m}$ hydrocortisone and 5 $\mu \mathrm{g} / \mathrm{ml}$ insulin (Huang et al., 2007); 4) Epithelial: DMEM 10\% ES-FBS 10\% with Glutamax, $5 \mu \mathrm{M}$ retinoic acid (Brzoska et al., 2005). Cells were seeded onto Matrigel ${ }^{\mathrm{TM}}$-coated plates prior to epithelial differentiation.

Mesenchymal lineages differentiation was assessed and quantified at 3 weeks as previously described, by staining with Oil Red $\mathrm{O}$ for adipogenic differentiation, Alizarin Red for osteogenic differentiation or Alcian blue for chondrogenic differentiation (Guasti et al., 2012). For epithelial and neural differentiation, the cells were analyzed after the specified length of time for gene and protein expression.

\section{Reverse transcription-polymerase chain reaction and quantitative real-time polymerase chain reaction}

RNA was extracted from biological replicates using Tri-Reagent (Life Technologies) according to the manufacturer's protocol and retrotranscribed with Moloney murine leukaemia virus reverse transcriptase (Promega). mRNA was quantified by real-time quantitative polymerase chain reaction using the Quantitect SYBR Green PCR kit (Qiagen) and the 7500-sequence detection system (Applied Biosysytems) following the manufacturer's instructions. A list of the primers and their squences are specified in Supplemental Table 1. Expression levels were normalised using the house keeping gene, GAPDH. Fold changes \pm SD were calculated taking either the control undifferentiated cells (differentiation experiments) or the parental line (pluripotency markers) as a reference. Statistical analysis was carried out by one-way ANOVA. P values $<0.05$ were considered significant.

\section{Immunofluorescence}

Cells were fixed in $4 \%$ PFA prior to immunofluorescence protein detection followed by washing multiple times with phosphate buffered saline (PBS), incubated with a blocking/permeabilizing buffer (10\% FBS, 3\% BSA, and $0.2 \%$ Triton-X100 in PBS) and then incubated overnight with the following primary antibodies: rabbit anti-ZO-1 (Life Technologies, 1:100 dilution in PBS), rabbit Anti NF-200 (Sigma, 1:200 dilution), mouse anti MAP2 (Life Technologies, 1:100 dilution). After washes, cells were incubated with secondary antibodies (Alexa Fluor 488 and 594, 1:400 dilution). Hoechst $33258(2 \mu \mathrm{g} / \mathrm{ml}$, Sigma) was added during secondary antibody incubation to counterstain the cell nuclei. Negative controls were incubated with the secondary antibody and Hoechst 33258 only. Images were acquired with an inverted microscope Olympus IX71 (Carl Zeiss, Jena, Germany) equipped with a Hamamatsu ORCA-ER digital camera (Hamamatsu Corp., Bridgewater, $\mathrm{NJ}$ ).

\section{Acknowledgements}

This study was supported by Newlife Foundation, NIHR GOSH BRC, $M R C$ and BBSRC and the Erasmus Programme.

\section{References}

AGRAWAL, V., JOHNSON, S.A., REING, J., ZHANG, L., TOTTEY, S., WANG, G. HIRSCHI, K.K., BRAUNHUT, S., GUDAS, L.J. and BADYLAK, S.F. (2010). Epimorphic regeneration approach to tissue replacement in adult mammals. Proc Natl Acad Sci USA 107: 3351-3355.

AKSOY, I., GIUDICE, V., DELAHAYE, E., WIANNY, F., AUBRY, M., MURE, M., CHEN, J., JAUCH, R., BOGU, G.K., NOLDEN, T. et al., (2014). Klf4 and Klf5 differentially inhibit mesoderm and endoderm differentiation in embryonic stem cells. Nat Commun 5: 3719 .

ARRIBAS, M.I., ROPERO, A.B., REIG, J.A., FRAGA, M.F., FERNANDEZ, A.F., SANTANA, A. and ROCHE, E. (2014). Negative neuronal differentiation of human adipose-derived stem cell clones. Regen Med 9: 279-93.

BADIMON, L. and CUBEDO, J. (2017). Adipose tissue depots and inflammation effects on plasticity and resident mesenchymal stem cell function. Cardiovasc Res 113: 1064-1073.

BAER, P.C. (2011). Adipose-derived stem cells and their potential to differentiate into the epithelial lineage. Stem Cells Dev 20: 1805-1816.

BEKHITE, M.M., FINKENSIEPER, A., REBHAN, J., HUSE, S., SCHULTZE-MOSGAU, S., FIGULLA, H.R., SAUER, H. and WARTENBERG, M. (2014). Hypoxia, leptin, and vascular endothelial growth factor stimulate vascular endothelial cell differentiation of human adipose tissue-derived stem cells. Stem Cells Dev 23: 333-351.

BERG, D.A., KIRKHAM, M., BELJAJEVA, A., KNAPP, D., HABERMANN, B., RYGE, J., TANAKA, E.M. and SIMON, A. (2010). Efficient regeneration by activation of neurogenesis in homeostatically quiescent regions of the adult vertebrate brain. Development 137: 4127-4134.

BERRY, R. and RODEHEFFER, M.S. (2013). Characterization of the adipocyte cellular lineage in vivo. Nat Cell Biol 15: 302-308

BLANCO, B., HERRERO-SANCHEZ, M.D., RODRIGUEZ-SERRANO, C., GARCIA-MARTINEZ, M.L., BLANCO, J.F., MUNTION, S., GARCIA-ARRANZ, M. SANCHEZ-GUIJO, F. and DEL CANIZO, C. (2016). Immunomodulatory effects of bone marrow versus adipose tissue-derived mesenchymal stromal cells on NK cells: implications in the transplantation setting. Eur J Haematol 97: 528-537.

BRZOSKA, M., GEIGER, H., GAUER, S. and BAER, P. (2005). Epithelial differentiation of human adipose tissue-derived adult stem cells. Biochem Biophys Res Commun 330: 142-150.

CRISAN, M., YAP, S., CASTEILLA, L., CHEN, C.W., CORSELLI, M., PARK, T.S., ANDRIOLO, G., SUN, B., ZHENG, B., ZHANG, L. et al., (2008). A perivascular origin for mesenchymal stem cells in multiple human organs. Cell Stem Cell3: 301-313.

CUI, X., HE, Z., LIANG, Z., CHEN, Z., WANG, H. and ZHANG, J. (2017). Exosomes From Adipose-derived Mesenchymal Stem Cells Protect the Myocardium Against Ischemia/Reperfusion Injury Through Wnt/beta-Catenin Signaling Pathway. J Cardiovasc Pharmacol 70: 225-231.

DA SILVA MEIRELLES, L., MALTA, T.M., DE DEUS WAGATSUMA, V.M., PALMA P.V., ARAUJO, A.G., RIBEIRO MALMEGRIM, K.C., MORATO DE OLIVEIRA, F., PANEPUCCI, R.A., SILVA, W.A., JR., KASHIMA HADDAD, S. et al., (2015). Cultured Human Adipose Tissue Pericytes and Mesenchymal Stromal Cells Display a Very Similar Gene Expression Profile. Stem Cells Dev 24: 2822-2840.

DE MATTEIS, R., ZINGARETTI, M.C., MURANO, I., VITALI, A., FRONTINI, A., GI- 
ANNULIS, I., BARBATELLI, G., MARCUCCI, F., BORDICCHIA, M., SARZANI, R. et al., (2009). In vivo physiological transdifferentiation of adult adipose cells. Stem Cells 27: 2761-2768.

DESIDERIO, V., DE FRANCESCO, F., SCHIRALDI, C., DE ROSA, A., LA GATTA, A., PAINO, F., D'AQUINO, R., FERRARO, G.A., TIRINO, V. and PAPACCIO, G. (2013). Human $\mathrm{Ng} 2+$ adipose stem cells loaded in vivo on a new crosslinked hyaluronic acid-Lys scaffold fabricate a skeletal muscle tissue. J Cell Physiol228: 1762-1773.

EMBREE, M.C., CHEN, M., PYLAWKA, S., KONG, D., IWAOKA, G.M., KALAJZIC, I., YAO, H., SHI, C., SUN, D., SHEU, T.J. et al., (2016). Exploiting endogenous fibrocartilage stem cells to regenerate cartilage and repair joint injury. Nat Commun 7: 13073.

FERRETTI, P. and GÉRAUDIE, J. (1998). Cellular and MolecularBasis of Regeneration: From Invertebrates to Humans. John Wiley and Sons, Ltd, Chichester, England.

FRIEDENSTEIN, A.J., PETRAKOVA, K.V., KUROLESOVA, A.I. and FROLOVA, G.P. (1968). Heterotopic of bone marrow. Analysis of precursor cells for osteogenic and hematopoietic tissues. Transplantation 6: 230-247.

GALENDE, E., KARAKIKES, I., EDELMANN, L., DESNICK, R.J., KERENYI, T., KHOUEIRY, G., LAFFERTY, J., MCGINN, J.T., BRODMAN, M., FUSTER, V. et al., (2010). Amniotic fluid cells are more efficiently reprogrammed to pluripotency than adult cells. Cell Reprogram 12: 117-125.

GAO, F., CHIU, S.M., MOTAN, D.A., ZHANG, Z., CHEN, L., JI, H.L., TSE, H.F., FU, Q.L. and LIAN, Q. (2016). Mesenchymal stem cells and immunomodulation: current status and future prospects. Cell Death Dis 7: e2062.

GEBLER, A., ZABEL, O. and SELIGER, B. (2012). The immunomodulatory capacity of mesenchymal stem cells. Trends Mol Med 18: 128-134.

GHOSH, S., THOROGOOD, P. and FERRETTI, P. (1996). Regeneration of lower and upper jaws in urodeles is differentially affected by retinoic acid. Int $J$ Dev Biol 40: 1161-1170.

GODWIN, J. (2014). The promise of perfect adult tissue repair and regeneration in mammals: Learning from regenerative amphibians and fish. Bioessays 36:861-871.

GOSS, J.M. (1969). Priciples of Regeneration. Academic Press, New York.

GRIFFIN, M.F., IBRAHIM, A., SEIFALIAN, A.M., BUTLER, P.E.M., KALASKAR, D.M. and FERRETTI, P. (2017). Chemical group-dependent plasma polymerisation preferentially directs adipose stem cell differentiation towards osteogenic or chondrogenic lineages. Acta Biomater 50: 450-461.

GUASTI, L., PRASONGCHEAN, W., KLEFTORIOUS, G., MUKHERJEE, S., THRASHER, A.J., BULSTRODE, N.W. and FERRETTI, P. (2012). High plasticity of paediatric adipose tissue-derived stem cells: too much for selective skeletogenic differentiation?. Stem Cells Trans Med 1: 384-395

GUASTI, L., VAGASKA, B., BULSTRODE, N.W., SEIFALIAN, A. and FERRETTI, P. (2014). Chondrogenic differentiation of adipose tissue-derived stem cells within nanocaged POSS-PCU bioscaffolds: a new tool for nanomedicine. Nanomedicine: NBM 10: 279-289.

GUILAK, F., LOTT, K.E., AWAD, H.A., CAO, Q., HICOK, K.C., FERMOR, B. and GIMBLE, J.M. (2006). Clonal analysis of the differentiation potential of human adipose-derived adult stem cells. J Cell Physiol 206: 229-237.

GUPTA, R.K., ARANY, Z., SEALE, P., MEPANI, R.J., YE, L., CONROE, H.M., ROBY, Y.A., KULAGA, H., REED, R.R. and SPIEGELMAN, B.M. (2010). Transcriptional control of preadipocyte determination by Zfp423. Nature 464: 619-623.

GUPTA, R.K., MEPANI, R.J., KLEINER, S., LO, J.C., KHANDEKAR, M.J., COHEN, P., FRONTINI, A., BHOWMICK, D.C., YE, L., CINTI, S. et al., (2012). Zfp423 expression identifies committed preadipocytes and localizes to adipose endothelial and perivascular cells. Cell Metab 15: 230-239.

HASS, R., KASPER, C., BOHM, S. and JACOBS, R. (2011). Different populations and sources of human mesenchymal stem cells (MSC): A comparison of adult and neonatal tissue-derived MSC. Cell Commun Signal 9: 12.

HU, L., WANG, J., ZHOU, X., XIONG, Z., ZHAO, J., YU, R., HUANG, F., ZHANG, H. and CHEN, L. (2016). Exosomes derived from human adipose mensenchymal stem cells accelerates cutaneous wound healing via optimizing the characteristics of fibroblasts. Sci Rep 6: 32993.

HUANG, T., HE, D., KLEINER, G. and KULUZ, J. (2007). Neuron-like differentiation of adipose-derived stem cells from infant piglets in vitro. J Spinal Cord Med 30 Suppl 1: S35-S40.

HYNES, K., MENICANIN, D., GRONTHOS, S. and BARTOLD, M.P. (2016). Differentiation of iPSC to Mesenchymal Stem-Like Cells and Their Characterization. Methods Mol Biol 1357: 353-374.
JOE, A.W., YI, L., EVEN, Y., VOGL, A.W. and ROSSI, F.M. (2009). Depot-specific differences in adipogenic progenitor abundance and proliferative response to high-fat diet. Stem Cells 27: 2563-2570.

KANG, T., JONES, T.M., NADDELL, C., BACANAMWO, M., CALVERT, J.W., THOMPSON, W.E., BOND, V.C., CHEN, Y.E. and LIU, D. (2016). Adipose-Derived Stem Cells Induce Angiogenesis via Microvesicle Transport of miRNA-31. Stem Cells Trans/ Med 5: 440-450.

LEE, M., BAN, J.J., KIM, K.Y., JEON, G.S., IM, W., SUNG, J.J. and KIM, M. (2016). Adipose-derived stem cell exosomes alleviate pathology of amyotrophic lateral sclerosis in vitro. Biochem Biophys Res Commun 479: 434-439.

LI, H., XU, Y., XIE, H., LI, C., SONG, L., FENG, C., ZHANG, Q., XIE, M., WANG, Y. and LV, X. (2014). Epithelial-differentiated adipose-derived stem cells seeded bladder acellular matrix grafts for urethral reconstruction: an animal model. Tissue Eng Part A 20: 774-784.

MACOTELA, Y., EMANUELLI, B., MORI, M.A., GESTA, S., SCHULZ, T.J., TSENG, Y.H. and KAHN, C.R. (2012). Intrinsic differences in adipocyte precursor cells from different white fat depots. Diabetes 61: 1691-1699.

MADEN, M. and HIND, M. (2003). Retinoic acid, a regeneration-inducing molecule. Dev Dyn 226: 237-244

MATSUMOTO, T., KANO, K., KONDO, D., FUKUDA, N., IRIBE, Y., TANAKA, N., MATSUBARA, Y., SAKUMA, T., SATOMI, A., OTAKI, M. et al., (2008). Mature adipocyte-derived dedifferentiated fat cells exhibit multilineage potential. J Cell Physiol 215: 210-222.

MELE, L., VITIELLO, P.P., TIRINO, V., PAINO, F., DE ROSA, A., LICCARDO, D. PAPACCIO, G. and DESIDERIO, V. (2016). Changing Paradigms in Cranio-Facia Regeneration: Current and New Strategies for the Activation of Endogenous Stem Cells. Front Physiol 7: 62.

MELIEF, S.M., ZWAGINGA, J.J., FIBBE, W.E. and ROELOFS, H. (2013). Adipose tissue-derived multipotent stromal cells have a higher immunomodulatory capacity than their bone marrow-derived counterparts. Stem Cells Trans/ Med 2: 455-463.

MILLER, F.D. and KAPLAN, D.R. (2012). Mobilizing endogenous stem cells for repair and regeneration: are we there yet? Cell Stem Cell 10: 650-652.

MURRAY, I.R. and PEAULT, B. (2015). Q\&A: Mesenchymal stem cells - where do they come from and is it important? BMC Biol 13: 99.

NEW, S.E., IBRAHIM, A., GUASTI, L., ZUCCHELLI, E., BIRCHALL, M., BULSTRODE, N.W., SEIFALIAN, A.M. and FERRETTI, P. (2017). Towards reconstruction of epithelialized cartilages from autologous adipose tissue-derived stem cells. $J$ Tissue Eng Regen Med 11: 3078-3089.

NEW, S.E.P., ALVAREZ-GONZALEZ, C., VAGASKA, B., GOMEZ, S.G., BULSTRODE, N.W., MADRIGAL, A. and FERRETTI, P. (2015). A matter of identity - Phenotype and differentiation potential of human somatic stem cells. Stem Cell Research 15:1-13.

PARK, E. and PATEL, A.N. (2010). Changes in the expression pattern of mesenchymal and pluripotent markers in human adipose-derived stem cells. Cell Biol Int 34: 979-984.

PAUL, S., SCHINDLER, S., GIOVANNONE, D., DE MILLOTERRAZZANI, A., MARIANI, F.V. and CRUMP, J.G. (2016). Ihha induces hybrid cartilage-bone cells during zebrafish jawbone regeneration. Development 143: 2066-2076.

PRASONGCHEAN, W., BAGNI, M., CALZAROSSA, C., DE COPPI, P. and FERRETTI, P. (2012). Amniotic fluid stem cells increase embryo survival following injury. Stem Cells Dev 21: 675-688.

RODEHEFFER, M.S., BIRSOY, K. and FRIEDMAN, J.M. (2008). Identification of white adipocyte progenitor cells in vivo. Cell 135: 240-249.

RODRIGUEZ, L.V., ALFONSO, Z., ZHANG, R., LEUNG, J., WU, B. and IGNARRO, L.J. (2006). Clonogenic multipotent stem cells in human adipose tissue differentiate into functional smooth muscle cells. Proc Natl Acad Sci USA 103: 12167-12172.

RYDEN, M., UZUNEL, M., HARD, J.L., BORGSTROM, E., MOLD, J.E., ARNER, E., MEJHERT, N., ANDERSSON, D.P., WIDLUND, Y., HASSAN, M. et al., (2015). Transplanted Bone Marrow-Derived Cells Contribute to Human Adipogenesis. Cell Metab 22: 408-417.

SANCHEZ-GURMACHES, J. and GUERTIN, D.A. (2014). Adipocyte lineages: tracing back the origins of fat. Biochim Biophys Acta 1842: 340-351.

SEALE, P., BJORK, B., YANG, W., KAJIMURA, S., CHIN, S., KUANG, S., SCIME, A., DEVARAKONDA, S., CONROE, H.M., ERDJUMENT-BROMAGE, H. et al., (2008). PRDM16 controls a brown fat/skeletal muscle switch. Nature 454: 961-967.

SIMKIN, J., SAMMARCO, M.C., DAWSON, L.A., SCHANES, P.P., YU, L. and MUNEOKA, K. (2015). The mammalian blastema: regeneration at our fingertips 
Regeneration (Oxf) 2: 93-105.

SIMKIN, J., SAMMARCO, M.C., MARRERO, L., DAWSON, L.A., YAN, M., TUCKER, C., CAMMACK, A. and MUNEOKA, K. (2017). Macrophages are required to coordinate mouse digit tip regeneration. Development 144: 3907-3916.

SLACK, J.M. (2017). Animal regeneration: ancestral character or evolutionary novelty? EMBO Rep 18: 1497-1508.

SPALLANZANI, L. (1768). Programme ou précis d'un ouvrage sur les réproductions animales Geneva.

SQUILLARO, T., PELUSO, G. and GALDERISI, U. (2016). Clinical Trials With Mesenchymal Stem Cells: An Update. Cell Transplant 25: 829-848.

STERN-STRAETER, J., BONATERRA, G.A., JURITZ, S., BIRK, R., GOESSLER, U.R., BIEBACK, K., BUGERT, P., SCHULTZ, J., HORMANN, K., KINSCHERF, R. et al., (2014). Evaluation of the effects of different culture media on the myogenic differentiation potential of adipose tissue- or bone marrow-derived human mesenchymal stem cells. Int $J$ Mol Med 33: 160-170.

STILLWELL, C., WANG, F., XIANG, B., DENG, J., KASHOUR, T., LIU, H., FREED, D., ARORA, R.C. and TIAN, G. (2012). Adipose tissue houses different subtypes of stem cells. Can J Physiol Pharmacol 90: 1295-1301.

STOCUM, D. (2006). Regenerative Biology and Medicine Academic Press, Canada.

STRECKFUSS-BOMEKE, K., WOLF, F., AZIZIAN, A., STAUSKE, M., TIBURCY, M., WAGNER, S., HUBSCHER, D., DRESSEL, R., CHEN, S., JENDE, J. etal., (2013). Comparative study of human-induced pluripotent stem cells derived from bone marrow cells, hair keratinocytes, and skin fibroblasts. Eur Heart J 34: 2618-2629.

STUBBENDORFF, M., DEUSE, T., HUA, X., PHAN, T.T., BIEBACK, K., ATKINSON, K., EIERMANN, T.H., VELDEN, J., SCHRODER, C., REICHENSPURNER, H. et al., (2013). Immunological properties of extraembryonic human mesenchymal stromal cells derived from gestational tissue. Stem Cells Dev 22: 2619-2629.

SUN, N., PANETTA, N.J., GUPTA, D.M., WILSON, K.D., LEE, A., JIA, F., HU, S., CHERRY, A.M., ROBBINS, R.C., LONGAKER, M.T. et al., (2009). Feeder-free derivation of induced pluripotent stem cells from adult human adipose stem cells. Proc Natl Acad Sci USA 106: 15720-15725.

SZARAZ, P., GRATCH, Y.S., IQBAL, F. and LIBRACH, C.L. (2017). In vitro Differentiation of Human Mesenchymal Stem Cells into Functional Cardiomyocyte-like Cells. J Vis Exp. 2017 Aug 9;(126). doi: 10.3791/55757

TCHKONIA, T., THOMOU, T., ZHU, Y., KARAGIANNIDES, I., POTHOULAKIS, C.,
JENSEN, M.D. and KIRKLAND, J.L. (2013). Mechanisms and metabolic implications of regional differences among fat depots. Cell Metab 17: 644-656.

THOMOU, T., MORI, M.A., DREYFUSS, J.M., KONISHI, M., SAKAGUCHI, M., WOLFRUM, C., RAO, T.N., WINNAY, J.N., GARCIA-MARTIN, R., GRINSPOON, S.K. et al., (2017). Adipose-derived circulating miRNAs regulate gene expression in other tissues. Nature 542: 450-455.

TIMMONS, J.A., WENNMALM, K., LARSSON, O., WALDEN, T.B., LASSMANN, T., PETROVIC, N., HAMILTON, D.L., GIMENO, R.E., WAHLESTEDT, C., BAAR, K. et al., (2007). Myogenic gene expression signature establishes that brown and white adipocytes originate from distinct cell lineages. Proc Natl Acad Sci USA 104: 4401-4406

TOH, W.S., LAI, R.C., HUI, J.H.P. and LIM, S.K. (2017). MSC exosome as a cell-free MSC therapy for cartilage regeneration: Implications for osteoarthritis treatment. Semin Cell Dev Biol 67: 56-64.

TRAN, K.V., GEALEKMAN, O., FRONTINI, A., ZINGARETTI, M.C., MORRONI, M., GIORDANO, A., SMORLESI, A., PERUGINI, J., DE MATTEIS, R., SBARBATI, A. et al., (2012). The vascular endothelium of the adipose tissue gives rise to both white and brown fat cells. Cell Metab 15: 222-229.

TZAHOR, E. and POSS, K.D. (2017). Cardiac regeneration strategies: Staying young at heart. Science 356: 1035-1039.

ULLAH, I., SUBBARAO, R.B. and RHO, G.J. (2015). Human mesenchymal stem cells - current trends and future prospective. Biosci Rep. 35. pii: e00191.

VIGNAIS, M.L., CAICEDO, A., BRONDELLO, J.M. and JORGENSEN, C. (2017) Cell Connections by Tunneling Nanotubes: Effects of Mitochondrial Trafficking on Target Cell Metabolism, Homeostasis, and Response to Therapy. Stem Cells Int 2017: 6917941.

WORTHLEY, D.L., CHURCHILL, M., COMPTON, J.T., TAILOR, Y., RAO, M., SI, Y., LEVIN, D., SCHWARTZ, M.G., UYGUR, A., HAYAKAWA, Y. et al., (2015). Gremlin 1 identifies a skeletal stem cell with bone, cartilage, and reticular stromal potential. Cell 160: 269-284.

ZHAO, H., FENG, J., HO, T.V., GRIMES, W., URATA, M. and CHAI, Y. (2015). The suture provides a niche for mesenchymal stem cells of craniofacial bones. Nat Cell Biol 17: 386-396.

ZIELINS, E.R., RANSOM, R.C., LEAVITT, T.E., LONGAKER, M.T. and WAN, D.C. (2016). The role of stem cells in limb regeneration. Organogenesis 12: 16-27. 


\section{Further Related Reading, published previously in the Int. J. Dev. Biol.}

Changes in the expression of cyclin dependent kinase inhibitors during differentiation of immortalized fibroblasts into adipocytes Ibon Alonso, Antonio Baroja, Blanca Fernández, Raquel Vielba, Jon Elorriaga, Jairo Pérez-Sanz, Juan Aréchaga, Juan J. Goiriena de Gandarias and Carmen de la Hoz

Int. J. Dev. Biol. (2017) 61: 89-93

https://doi.org/10.1387/ijdb.160416cd

\section{Growth factor-defined culture medium for human mesenchymal stem cells}

Sumiyo Mimura, Naohiro Kimura, Mitsuhi Hirata, Daiki Tateyama, Midori Hayashida, Akihiro Umezawa, Arihiro Kohara, Hiroki Nikawa, Tetsuji Okamoto and Miho K. Furue

Int. J. Dev. Biol. (2011) 55: 181-187

https://doi.org/10.1387/ijdb.103232sm

\section{Adipocyte is a non-trivial, dynamic partner of breast cancer cells}

Jinxiang Tan, Emilie Buache, Marie-Pierre Chenard, Nassim Dali-Youcef, Marie-Christine Rio

Int. J. Dev. Biol. (2011) 55: 851-859

https://doi.org/10.1387/ijdb.113365jt

Pdx1-transfected adipose tissue-derived stem cells differentiate into insulin-producing cells in vivo and reduce hyperglycemia in diabetic mice

Hiromitsu Kajiyama, Tatsuo S. Hamazaki, Makoto Tokuhara, Shinji Masui, Koji Okabayashi, Kiyoshi Ohnuma, Shigeharu Yabe, Kazuki Yasuda, Shoichi Ishiura, Hitoshi Okochi and Makoto Asashima

Int. J. Dev. Biol. (2010) 54: 699-705

https://doi.org/10.1387/ijdb.092953hk

Pdx1-transfected adipose tissue-derived stem cells differentiate into insulin-producing cells in vivo and reduce hyperglycemia in diabetic mice

Hiromitsu Kajiyama, Tatsuo S. Hamazaki, Makoto Tokuhara, Shinji Masui, Koji Okabayashi, Kiyoshi Ohnuma, Shigeharu Yabe, Kazuki Yasuda, Shoichi Ishiura, Hitoshi Okochi and Makoto Asashima

Int. J. Dev. Biol. (2010) 54: 699-705

https://doi.org/10.1387/ijdb.092953hk

Genetic and epigenetic instability of human bone marrow mesenchymal stem cells expanded in autologous serum or fetal bovine serum

John-Arne Dahl, Shivali Duggal, Neralie Coulston, Douglas Millar, John Melki, Aboulghassem Shahdadfar, Jan E. Brinchmann and Philippe Collas

Int. J. Dev. Biol. (2008) 52: 1033-1042

https://doi.org/10.1387/ijdb.082663jd

5 yr ISI Impact Factor $(2016)=2.421$
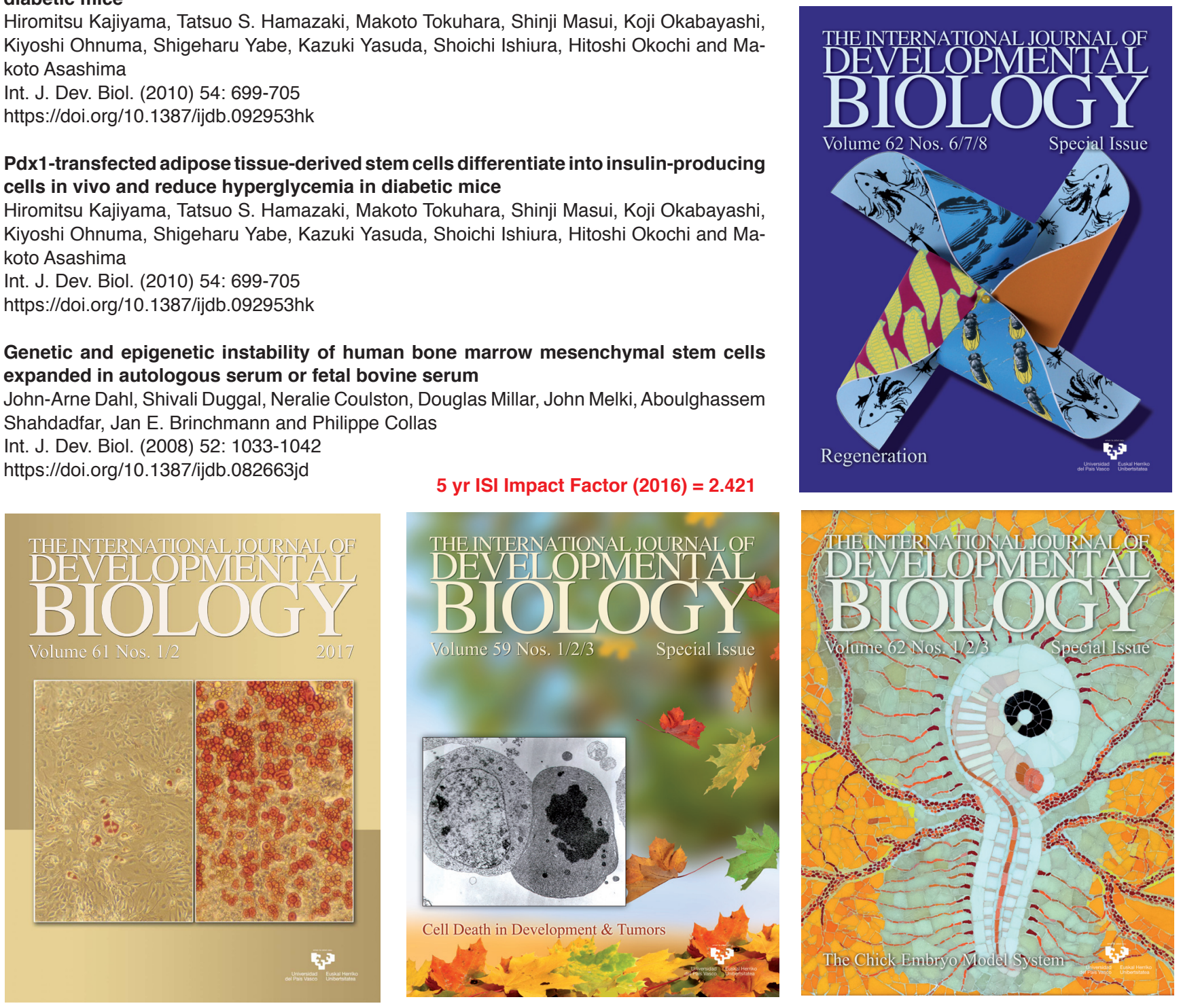